unlikely that this analysis would be rigorously applied by the courts. In this case, no more than in the other cases, can the value of the right to retain be determined. But it seems more probable that nonperishable property will have some value upon the lifting of controls, and that the controls will be lifted. The courts would undoubtedly find compensation due in such a case.

The same considerations could be applied to certain cases involving the government program prices. These prices were not directly reviewable as were the OPA ceiling prices. Consequently, where the program price is so low as to amount merely to a fiat price, the resulting situation is essentially the same as where trading is completely restricted.

If in cases like the above there is to be compensation, its measure should be free from confusion and easily determinable. In view of the completely speculative nature of retention value, the best rule-of-thumb in such circumstances would probably be to award the last quoted market price for the property, whether it be the price of a free or controlled market.

\title{
MIGRATORY DIVORCE IN AUSTRALIA AND THE UNITED STATES
}

Recent decisions and discussions have emphasized abundantly the acuteness of the country's interstate divorce problem. ${ }^{x}$ Perhaps a study of the fundamental aspect of the problem, the theory of "states' rights" to control divorce policy, coupled with a brief restatement of the uncertainty a "Nevada" decree casts upon subsequent legal relations of the parties may serve to accentuate its pressing nature as well as the difficulties of achieving a solution. It does not seem necessary to repeat all that has been said of attempted American solutions and the reasons for their failure. However, for the purpose of clarifying the American situation, a rather detailed discussion of the history of interstate divorce in the Commonwealth of Australia is attempted here. Although, to be sure, the Australian treatment cannot be realistically advanced as a solution for this country, the differences and similarities of the two legal systems on this problem have been phrased in terms of possible American adoption of the Australian program. The strength of this comparative method is founded on similarities between the legal systems of the two nations. Both spring from the same common law and are affected insofar as jurisdiction in divorce is concerned by similar constitu-

I Estin v. Estin, 334 U.S. 54I (I948); Williams v. North Carolina, 325 U.S. 226 (1945); Llewellyn, Behind the Law of Divorce, 32 Col. L. Rev. I28I (1932); Powell, And Repent at Leisure, 58 Harv. L. Rev. 930 (I945); Lenhoff, The Rationale of the Recognition of Foreign Divorces in New York, I6 Fordham L. Rev. 23 I (1947); J. M. Radin, The Interstate Divorce Problem, 69 N.J. L.J. 233 (r946). For an interesting decision shedding light upon early conflicts problems when states based jurisdiction variously on domicile, place where the cause of action arose, place of marriage, see Ditson v. Ditson, 4 R.I. 87 (I856). Footnote I $_{3}$ of Justice Frankfurter's dissent in Sherrer v. Sherrer, 334 U.S. 343, 364 (1948), traces briefly recent attempts to solve the problem. 
tional and statutory provisions. Both operate in dual state-federal governmental organizations.

The most fundamental and characteristic feature of the problem of divorce jurisdiction is common not only to the jurisprudence of the United States and Australia but is universal. It arises from the fact that the dissolution of a marriage not only affects the immediate parties but is a matter in which the entire community feels that it may claim a legitimate interest. This notion finds expression in the statement that the "state is a party to a marriage contract." Indeed, the state writes the contract. To render of value the otherwise legally unenforceable promise of the parties to "love, honor, and obey," common law and statutes speak of conjugal "rights," the "right" of dower, community property "interests," the "duty" to cohabit and to support. These implied rights and duties benefit the married couple, to be sure. But, since marriage performs functions which society, in its absence, would be at loss to perform for itself, the state gains a reward of its own by insisting on the implication of these terms. Through the marriage home, for example, the state gains many separate institutions where its younger generations may be fed, clothed, refined into socially compatible and socially responsible individuals. Because social custom treats marriage as a regulator of sexual conduct, the state is freed of much conflict of men over women. For the wife marriage is, in a very real sense, a sort of old age insurance, a means of support "independent of continuing sex charm." In addition, the problems of adjustment and concession intrinsic in successful marital partnership provide the essentially selfish nature of the normal individual a launching point for growth of the spirit of community co-operation and good citizenship.

To protect these interests in the proper functioning of marriage, society does not want divorce made "too" easy. Unrestrained divorce would sanction marriage intended only to legitimize otherwise illicit relationships. On the other hand, divorce is an instrument which salvages matrimonial wreckage. It enables the non-offending spouse to look elsewhere for happiness and security and gives the state an opportunity to profit by the renewed marital capacity of two citizens. To the extent that divorce is made "too" difficult that opportunity is denied. It thus becomes apparent that the wise state will draw a line somewhere in the middle ground between divorce laws which it deems "too" strict and those "too" liberal.

In the United States, as everyone knows, forty-eight state legislatures lay down various "grounds" for divorce. Few of the lines thus independently determined between the laws "too" strict and those "too" liberal are drawn at the same place, either in statutory law or in practice. 3 Tendencies toward "strict" divorce in some areas have been explained by the existence of predominating

2 Llewellyn, Behind the Law of Divorce, 32 Col. L. Rev. I28I, r29o (r932). This article suggests the argument in the text concerning the place of marriage in modern society.

3 Statistics, note 48 infra. 
religious or national groups, in others by the conservatism of rural populations. 4 On the other hand frontier states were influenced toward more liberal rules by early shortages of women. ${ }^{5}$ Whatever the merits of these influences, the American community does not yet seem prepared to dismiss the notion that each state should be allowed to make up its own mind about divorce. It is felt that the divorce law of one state should be compulsory on the "domiciliaries" of that state. As a corollary it is said that the courts of the individual states should not dissolve the marriage of a stranger to the state unless it appears that there has been established ". . . a nexus between person and place of such permanence as to control the creation of legal relations of the utmost significance."

From this "states' rights" theory arises the puzzling nature of the problem. A New Yorker, for example, who is given but one "ground" for divorce under the New York statutes, seeks more favorable law elsewhere. If he is fortunate a six weeks' stay in Nevada and an ex parte decree under Nevada's liberal divorce procedure will answer his problem. However, because Nevada can have no interest in his marital relationship unless Nevada can claim him as a "domiciliary," it is demanded of him by Nevada that he acquire "domicile" within that state through "six weeks' residence plus an intent to remain indefinitely." Such an intent his complaint alleges, but Nevada requires little proof of the pleading.7 It is clear that the practice of "migration" has tended to evade the notions of the New York legislature about the marital institution. If allowed to go unchecked such a procedure would "cheat" and importantly change New York law. ${ }^{8}$ However, a means is presented whereby New York may vindicate her policy. Repeatedly it has been said that New York need not by any constitutional mandate of "full faith and credit" recognize the Nevada court's finding of domicile as binding upon it.9 Legal terminology says that the Nevada court had "no

4 Groves, Migratory Divorce, 35 Law \& Contemp. Prob. 293, 295 (I935).

5 That this was the initial reason for Nevada's liberality, see Ingram and Ballard, The Business of Migratory Divorce in Nevada, 35 Law \& Contemp. Prob. 302, 303 (I935).

${ }^{6}$ Williams v. North Carolina, 325 U.S. 226, 229 (I945).

7 "It may be a matter of "common knowledge that his home and his business are in New York, but no specific questions are asked as to why he left New York or came to Nevada and filed his case by the stop-watch. The courts have no hesitancy in accepting this general statement as establishing the good faith of his residence. ..." Ingram and Ballard, The Business of Migratory Divorce in Nevada, 35 Law \& Contemp. Prob. 302, 308 (1935).

8 " $O$ f what use would it be for State 'A' to require domicil as a condition of jurisdiction in divorce and to allow divorces only for desertion for three years, if neighboring State ' $\mathrm{B}$ ' allowed divorce for bad temper and required only service of process within the territory of State ' $B$ ' and then State ' $A$ ' were compelled by the full faith and credit clause to recognize that its citizens had been duly divorced in State 'B'?" Harris v. Harris (1947) V.L.R. 44; Powell, op. cit. supra note $I$, at 957 .

9 "To permit the necessary finding of domicil by one State to foreclose all States in the protection of their social institutions would be intolerable." Williams v. North Carolina, 325 U.S. 226, 232 (1945). 
power over the individual or the subject matter." The "nexus between person and place," domicile, was lacking. In any future New York litigation her courts may, if they wish, treat Nevada's ex parte decree as a nullity. ${ }^{10}$

It goes almost without saying that the ability of one state or country to declare that one of its citizens is married when another state says that he is not complicates life for the individual seriously. But unfortunately these complications are not confined to those who consciously seek to avoid the laws of their own states. Justice Jackson, dissenting in Estin v. Estin, pointed out that "today many people who have simply lived in more than one state do not know [rules of law which will enable them to tell whether they are married or not and, if so, to whom] and the most learned lawyer cannot tell them with any confidence. The uncertainties that result are not merely technical, nor are they trivial; they affect fundaraental rights and relations such as the lawfulness of their cohabitation, their children's legitimacy, their title to property, and even whether they are law-abiding persons or criminals." "The drive to eliminate the "uncertainty" mentioned by Justice Jackson and the "states' rights" theory discussed above compose the competing elements of the interstate divorce problem. The uncertainties will be discussed briefly under four major divisions.

Uncertainty begins, of course, when the court seeks to determine the bona fides of a man's "intent" to remain in the foreign state. Justice Rutledge, dissenting in the second Williams case, pointed up the difficulty:

The very name [domicile] gives forth the idea of home with all its ancient associations of permanence. But "home" in the modern world is often a trailer or a tourist camp. The automobile, nation-wide business and multiple family dwelling units have deprived the institution, though not the idea, of its former general fixation to soil and locality. But, beyond this, "home" in the domiciliary sense can be changed in the twinkling of an eye, the time it takes a man to make up his mind to remain where he is when he is away from home. He need do no more than decide, by a flash of thought, to stay "either permanently or for an indefinite or unlimited length of time."

ro Of course, wherever sincere domiciliary intent is found, constitutional full faith and credit must be given the foreign decree. This is so regardless of variance in divorce law between the state rendering the decree and the state testing its power to do so. Sherrer v. Sherrer, 334 U.S. 343 (1948); Coe v. Coe, 334 U.S. 378 (r948). This is so regardless of the fact that the defendant did not appear before the foreign court and was not personally served process within the rendering state. Williams v. North Carolina, 317 U.S. 287 (1942), overruling Haddock v. Haddock, 201 U.S. 562 (1906).

II 334 U.S. 54I, 553 (I948).

${ }^{22}$ Williams v. North Carolina, 325 U.S. 226, 257 (I945). Justice Black, in the same case, carries the notion further: "... a divorced person's liberty, so far as this North Carolina statute [penal offense for bigamous cohabitation] is concerned, hinges on his ability to 'guess' at what may ultimately be the legal and factual conclusion resulting from a consideration of two of the most uncertain word symbols in all the judicial lexicon, 'jurisdiction' and 'domicile."” Ibid., at 277 . 
Although objective indicia may be plentiful, the test remains subjective in the close case. For this reason a simple term of residence within the foreign state has been suggested as a substitute jurisdictional criterion. ${ }^{33}$

If domiciliary intent is lacking, the home state need not by any constitutional requirement recognize a foreign decree which purports to divorce one of its citizens. It may do so if it wishes, however. The permissive nature of this recognition gives rise to a second sort of uncertainty. Each state may choose all, any, or none of three very different principles, on a descending scale of strictness, to guide it in the matter: res judicata, estoppel, comity. As between the parties to a foreign divorce action, if both appear and the question of domicile is litigated before the foreign court, neither can attack collaterally the decree's jurisdictional recital. Res judicata applies. ${ }^{{ }^{4} 4}$ Even where the nonprocuring spouse appears in the foreign state and fails to litigate the issue of domicile, some courts declare the matter to be res judicata if a fair opportunity to litigate was presented but ignored..5 Other states refuse unless the matter was thrashed out in an adversary proceeding. ${ }^{16}$ Some states estop the nonprocuring spouse who makes no appearance at all if there appears evidence of acquiescence in the foreign divorce by remarriage ${ }^{17}$ or acceptance of an agreement to support. ${ }^{18}$ The liberal use of principles of comity by New York courts has had the effect of broadening the grounds for divorce in that state. ${ }^{19}$ On the other hand, legislative mandate has ordered Massachusetts courts to refuse comity under all circumstances. There an "evasion" statute declares, in effect, that if a Massachusetts inhabitant goes to another state for the purpose of obtaining a divorce for a cause which occurred in Massachusetts or for a cause which would not authorize divorce under Massachusetts law, the courts of that state shall treat the foreign decree as a nullity. ${ }^{20}$ Other states have followed suit:2r

${ }^{13}$ Ibid., at 256; Powell, op. cit. supra note $x$, at roro. For an opposing view see J. M. Radin, The Interstate Divorce Problem, 69 N.J. L.J. 233, 247 (I946).

${ }_{44}$ Estin v. Estin, 334 U.S. 54I (x948); Coe v. Coe, 334 U.S. 378 (1948); Stoll v. Gottlieb, 305 U.S. 165 (1938); Davis v. Davis, 305 U.S. 32 (1938); Baldwin v. Iowa State Traveling Men's Ass'n., 283 U.S. 522 (I93I).

xs Glaser v. Glaser, 276 N.Y. 296, I2 N.E. $2 d$ 305 (x938); Tiedemann v. Tiedemann, 225 N.Y. 709, I22 N.E. 892 (I917), writ of error dismissed 251 U.S. 536 (I9I9); Kinnier v. Kinnier, 45 N.Y. 535 (r87r). Contra: Solotoff v. Solotoff, 269 App. Div. 677,53 N.Y.S. 2 d 5Io (r945); In re Lindgren's Estate, 293 N.Y. 18, 55 N.E. $2 d 849$ (r944).

${ }^{16}$ Cohen v. Cohen, 3 I9 Mass. $3^{x,} 64$ N.E. $2 d 689$ (I946).

17 Carbulon v. Carbulon, 293 N.Y. 375, 57 N.E. 2d 59 (r944).

${ }^{18}$ Schacht v. Schacht, 295 N.Y. 439, 68 N.E. $2 d 433$ (I946).

19 Glaser v. Glaser, 276 N.Y. 296, I2 N.E. $2 d 305$ (r938).

${ }^{20}$ Mass. Ann. Laws (I933) c. 208, $\S 39$.

${ }_{21}$ Me. Rev. Stat. (I944) c. I53, $\$ 66$; N.J. Rev. Stat. (I937) tit. 2, c. 50, $\$ 35$; Wis. Stat. (Brossard, I947) $\$ 247.21$. Early decisions of the Supreme Court held these acts constitutional. A citizen who left his state "for the purpose" of divorce could not meet the jurisdictional requirement of domicile ("presence with intent to remain") necessary to place the foreign decree under the protection of the full faith and credit clauses. Andrews v. Andrews, I88 U.S. I4 (Ig02); see Coe v. Coe, 3 I6 Mass. 423, 55 N.E. $2 d$ 702 (I944), overruled 334 U.S. 373 (I948); 
Since res judicata or estoppel can apply only to the immediate parties to the divorce action, uncertainty is multiplied by the possibilities of third-party attack.22 Thus, for example, participants in marriage subsequent to a colorable divorce have been allowed decrees of nullity on grounds of the marital incapacity of their spouses. Generally nullity decrees have been granted where the remarried party was not the plaintiff in the prior proceeding ${ }^{23}$ and occasionally where he was. ${ }^{24}$ Such a decree has been granted even where the petitioning party advised and aided the other to obtain the questionable divorce. ${ }^{25}$ Under present law if the divorced wife of the first marriage was before the court and litigated the problem of domicile, she could not later collaterally attack. ${ }^{26}$ However, if she appeared but did not litigate, or if she did not appear, the first wife might deprive a second wife of letters of administration or dower rights in the decedent husband's estate. Where the first wife has not acquiesced by her own remarriage or by receiving benefits based upon the foreign decree she is almost sure to succeed. ${ }^{27}$ In some jurisdictions she may succeed despite acquiescence. ${ }^{28}$

Langewald v. Langewald, 234 Mass. 269 , I25 N.E. 566 (r920). Recent decisions of the Supreme Court, however, have seriously impaired the efficacy of these statutes where both husband and wife left the state and litigated the issue of domicile. Coe v. Coe, 334 U.S. 378 (I948); Sherrer v. Sherrer, 334 U.S. 343 (1948). An interesting bit of uncertainty occurred in connection with the revision of such a statute in the State of Delaware. Delaware's "evasion" statute used much the same language as the Massachusetts statute above. Del. Rev. Code (r935) $\$ 3525$. A r945 amendment read, "Full faith and credit shall be given in all Courts of this State to a decree of annulment of marriage or divorce by a court of competent jurisdiction in another State, Territory or possession." 45 Laws of Del. (r945) c. 225. In State v. Nixon, 46 A. 2d 874 (Del. Gen. Sess., 1946) the Court admitted, arguendo, that the r945 amendment demanded full faith regardless of domicile. However, in State v. Long, 59 A. 2d 545 (Del. Gen. Sess., I948) the Court interpreted "competent jurisdiction" to mean jurisdiction over the subject matter and parties, as well as statutory power of the court to act in divorce. Thus a remarried foreign divorcee was convicted of bigamy.

23 ". . . those not parties to a litigation ought not to be foreclosed by the interested actions of others. ..." Williams v. North Carolina, 325 U.S. 226, 230 (I945).

${ }_{23}$ De Marigny v. De Marigny, 8I N.Y.S. 2d 228 (S. Ct., I948); Davis v. Davis, 279 N.Y. 656, 18 N.E. $2 d$ 3or (I928). Contra: Bane v. Bane, 80 N.Y.S. 2d 641 (S. Ct., x948).

${ }_{24}$ Jackson v. Jackson, 274 App. Div. 43, 79 N.Y.S. 2d 736 (I948). But cf. Mumma v. Mumma, I94 P. 2d 24 (Cal. App., I948) (Mexican divorce). The rule in the case last cited, by denying a nullity decree to the second wife of a husband who has procured a foreign divorce decree, places the second wife in a precarious position upon the death of her husband. His former wife may deprive her of rights under intestacy statutes as well as her rights to community property in those states which continue to recognize such an interest. As will appear, the benefits of Social Security may be denied her, as well as insurance with private firms. If her husband's will read "to my wife," without mention of his second wife's name, there is no reason why the first wife could not substantiate a claim under the will, leaving the second wife penniless. A nullity decree is her only protection against insecurity after her husband's death. A denial seems unreasonable.

${ }_{25}$ Jackson v. Jackson, 274 App. Div. 43, 79 N.Y.S. 2d 736 (1948).

${ }^{26}$ Coe v. Coe, 334 U.S. 378 (r948); Sherrer v. Sherrer, 334 U.S. 343 (I948).

${ }^{27}$ Rice v. Rice, I34 Conn. 440, 58 A. 2 d 523 (I948) (First wife takes administration of husband's estate from second wife); Vaughan v. Vaughan, 25 N.J. Misc. 340, 53 A. 2 d 625 (I947) (Second wife deprived of dower rights by first wife).

${ }^{23}$ True of the Mexican divorce cases: In re Hensgen's Estate, 18 r P. $2 d$ d 69 (Cal. App., 
Children of the first marriage have been allowed to question the second marriage on grounds of the invalidity of the first divorce in order to eliminate the second spouse as sole intestate heir of their father ${ }^{29}$ or to obtain an adjudication that their father's will had not been revoked by his remarriage. ${ }^{30}$ Occasionally litigation seeking similar ends has failed if the decedent father procured the prior divorce, 'since the children are estopped, as their father would have been. ${ }^{3 x}$ A child conceived to the first couple after dissolution of their marriage has succeeded in establishing his legitimacy. ${ }^{32}$ However, in one case, children of a prior marriage of a husband have not been able to attack the status of his later wife on grounds that a divorce which she obtained from her first husband was invalid. ${ }^{33}$ In one interesting situation the court allowed the first wife to contest the decedent's mother's intestacy rights. ${ }^{34}$

The state may always question the second marriage on the basis of invalidity of a prior divorce. Such actions may take the form of bigamy prosecutions. ${ }^{35} \mathrm{~A}$ recent case in which the Social Security Board refused payments to the second wife of a deceased Mexican divorcee illustrates other possibilities of confused and uncertain status. ${ }^{36}$ There seems no reason why private insurance companies could not similarly attack the validity of a migratory divorce decree. Executors of the estate of the second wife of a husband-divorcé have successfully attacked his rights to survivorship in joint tenancy property. ${ }^{37}$ Another novel situation allowed a nonprocuring husband to escape a suit for specific performance of a land contract on grounds that a previous invalid divorce left his wife's dower rights intact..$^{8}$

Occasionally a fourth type of uncertainty lies in the fact that a divorce decree may be valid in some respects, invalid in others. Thus, though a Florida decree

I947); In re McNutt's Estate, 98 P. 2 d 253 (Cal. App., I940); cf. Kelsey v. Miller, 203 Cal. 6I, 263 Pac. 200 (rg28).

${ }^{29}$ Olmstead v. Olmstead, rgo N.Y. 458,83 N.E. 569 (Ig08), aff'd 216 U.S. 386 (Igro); German Savings \& Loan Society v. Dormitzer, I92 U.S. I25 (I903).

${ }^{30}$ In re Lindgren's Estate, 293 N.Y. I8, 55 N.E. 2 d 849 (I944); In re Sayle's Estate, 80 N.E. 2d 22x, 229 (Ohio App., I948) (Children failed since evidence inconclusive).

${ }^{31}$ Shea v. Shea, 270 App. Div. 527,60 N.Y.S. 2d 823 (r946).

${ }^{3 \pi}$ Urquhart v. Urquhart, 272 App. Div. 60, 69 N.Y.S. $2 d 57$ (I947). One wonders what the status of the second wife and her children then must be.

33 In re Davis' Estate, $3_{8}^{8}$ Cal. App. 2d 579, Ior P. 2d 76r (r940), rehearing denied ro2 P. 2d 545 (1940).

34 In re Bruneman's Estate, 32 Cal. App. 2d 606, $9 \circ$ P. 2d 323 (r939).

35 Williams v. North Carolina, 325 U.S. 226 (I945). For a collection of editorial comment on the Williams decision see 91 Cong. Rec. 5179 (I945).

${ }^{6}$ Sherman v. Federal Security Agency, Social Security Board, 7o F. Supp. 758 (N.J., x947) noted in 15 Univ. Chi. L. Rev, 220 (r947).

37 Kelsey v. Miller, 203 Cal. 6r, 263 Pac. 200 (r928).

${ }_{38}$ McCreery v. Davis, 44 S.C. I95, 22 S.E. 178 (r895). 
has been effective to establish in each participant a renewed capacity to marry, it was held invalid insofar as it purported to grant custody of children who were not within the jurisdiction of the court. ${ }^{39} \mathrm{~A}$ decree permitting remarriage has been held impotent to alter post-marriage obligations to support.40

It has been said that uncertainty "is merely one of those untoward results inevitable in a federal system" ${ }^{4}$ which permits forty-eight state governments to establish and protect forty-eight different divorce policies. The consequent confusion and personal hardship have brought forth four recognizable patterns of possible solution. The first, a Uniform State Divorce law, has failed to gain acceptance by state legislatures in all but three states. ${ }^{42}$ The second, a recent Uniform Divorce Recognition Act, is not likely to achieve greater success. The differences, for example, between Massachusetts policy and New York policy in granting extraterritorial effect to decrees unprotected by the full faith and credit clauses would seem to make such a statute impractical even in its current "rule of evidence" form. ${ }^{43}$ The theory of these two solutions seems fundamentally in error in that it is dependent upon individual state action. It seems difficult to expect state lawmakers to volunteer action in matters as politically explosive as marriage and divorce policy.

The third and fourth solutions call for federal intervention rather than voluntary individual state action. Under the Constitution Congress has the power to "prescribe the manner in which [the judgments of one state, appearing in the forums of another] shall be proved, and the effect thereof." 44 Thus Congress might enact legislation similar to that of the Judiciary Act of I 790 but special to the circumstances of divorce. 45 Under this power legislation substantially codifying present case law was presented to the 80 th Congress. ${ }^{6}$ The fourth solution

39 In re Biggers, 228 N.C. 743,47 S.E. 2 d 32 (I948).

to Estin v. Estin, 334 U.S. 54 I (I948); Davis v. Davis, 70 Colo. 37, I97 Pac. 24 I (I92I).

1: Williams v. North Carolina, 325 U.S. 226, 237 (r945).

${ }^{42}$ That changes in divorce law frighten Australian as well as American politicians, see $x_{49}$ Commonwealth of Australia Parliamentary Debates 597 (1936), quoting Law Inst. J. 185 (I934): "The particular part about the matter [of uniform divorce law] is that, although most people favor the idea, the question is continually shelved and looks like remaining shelved until there is suffiently powerful agitation to force the Commonwealth's hand. All political parties seem afraid that by introducing a bill they will rend asunder their party...."

${ }^{43}$ Section I of the Uniform Divorce Recognition Act is similar to the Massachusetts Act, note 21 supra. It provides that no sister-state divorce decree shall be effective within the enacting state if the parties were domiciled within that state at the time of commencement of proceedings. It thus renders impossible application of doctrines of estoppel or comity by the judiciary. The second section of the Act provides that a) resumption of residence within the enacting state within eighteen months, or b) continual maintenance of a place of residence within the enacting state shall be prima facie evidence of retention of domicile by a resident of the enacting state who has sought a foreign divorce.

14 U.S. Const. Art. 4, §I.

15 I Stat. I22 (r79o), 28 U.S.C.A. $\$ 687$; Sherrer v. Sherrer, 334 U.S. 343,364 (1948); Powell, op. cit. supra note $x$, at rox 1 . Other authorities are collected in 94 Cong. Rec. 60 (I948).

${ }_{15}^{6}$ Senator McCarron of Nevada seeks passage of a statute designed to extend validity to decrees which are questionable under present law. S. 1960, 8oth Cong. 2d Sess. (1948). 
would require a constitutional amendment giving the federal government full power to legislate in matters of marriage and divorce. A clear understanding of the possibilities and effect of securing such an amendment may be gained, perhaps, by examining the Australian legal system as it touches the subject.

Until quite recently Australian divorce recognition law was surprisingly analogous to that of the United States. Variance in "grounds" for divorce between the Australian States, ${ }^{47}$ while not as great as that existing between the United States ${ }^{48}$ was substantial. ${ }^{49}$ The jurisdictional criterion, as in all commonlaw countries, was the elusive concept "domicile." ${ }^{50}$ As in the United States, the extraterritorial effect of a sister-state decree depended on the power of the rendering court over the parties and the subject matter, ${ }^{5 x}$ despite constitutional and statutory full faith and credit provisions..$^{52}$

Here the similarities end, however. The differences in the constitutional, statutory, and judge-made law of the two nations, substantial as subsequent dis-

47 Among the Australian States and Territories, adultery is a ground for divorce in all ro; habitual drunkenness, 9; imprisonment, 9; frequent convictions for five years, 9; attempt on spouse's life, 9 ; rape, sodomy, bestiality, 9; insanity, 7; desertion, three years, 8; desertion, five years, 2 ; incestuous adultery, 4 ; repeated assaults and beatings, 7 ; failure to obey maintenance decree or agreement, 4; failure to comply with restitution decree, 4; separation, 2; wife's pregnancy at marriage, I. Grounds for Divorce, Ig Aust. L.J. 333 (I946).

$4^{8}$ Out of fifty-four American jurisdictions reported in 3 Nelson, Divorce and Annulment, 6x 5-47 (2d ed. 1945), adultery is a ground for divorce in 53; imprisonment, crime, felony, 45; cruelty, severity, 43; desertion, 36 ; impotency, 35 ; habitual drunkenness, 34 ; abandonment or neglect, 33; insanity, mental illness, 26 ; separation, $x_{7}$; prior pregnancy, 14 ; former marriage, bigamy, I2; intemperance, II; drugs, II; mental suffering, 9; indignities, 8 ; injurious treatment, violence, 7; fraudulent contract, 5; attempting life of spouse, 4; outrages, 4; force, duress, 4; continual absence, 4; wilful absence, 4; consanguinity or affinity, 4; wife libel, defamation, 3 ; foreign divorce, 3 ; mental incapacity, idiocy, 2; vagrancy, 2; fugitive, 2; crime against nature, 2; incompatibility, 2; venereal disease, 2; anti-cohabitation beliefs, 2; violent temper, 2; corruption, prostitution, $I$; prior prostitution, $x$; wickedness, $I$; separation and nonsupport, $\mathrm{x}$; void or voidable marriage, $\mathrm{r}$; null and void marriage, $\mathrm{I}$; under age marriage, unconfirmed, I; leprosy, I; false prostitution charge, I. In South Carolina, the only state prohibiting divorce at the publication of Nelson's second edition, a recent referendum voted to amend a 63 -year-old constitutional ban, to permit divorce on grounds of physical cruelty, desertion, habitual drunkenness, or adultery. N.Y. Times, p. 2, col. 3 (Nov. 3, 1948).

49 I84 Commonwealth of Australia Parliamentary Debates 4833,4837 (x945); $x 49$ ibid., at 592,597 (1936).

so LeiMesurier v. LeMesurier, (I895) A.C. 517 ; Bell v. Bell, I8I U.S. I75 (I90I); Barber v. Barber, 2 I How. (U.S.) 582 (I858). Australian decisions: Kane v. Kane, (r939) Q.W.N. $5^{8}$; Slater v. Slater, (I928) S.A.S.R. I6I; Donald v. Donald, (1899) 9 Q.L.J. 2II.

$5 x$ Mackenzie v. Manwell, 20 W.N. (N.S.W.) I8 (xgo3); D'Arcy v. Ketchum, II How. (U.S.) I65 (1850); Thompson v. Whitman, I8 Wall. (U.S.) 457 (1873).

$5^{2}$ The Commonwealth Constitution provides: "Full faith and credit shall be given throughout the Commonwealth to the laws, the public acts and records, and the judicial proceedings of every State." Aust. Const. Act, § II8 (Ig00). Compare U.S. Const. Art. 4, § I. Implementation of this clause by Parliament followed the provisions of an American Act: "All public acts, records and judicial proceedings of any State or Territory ... shall have such faith and credit given to them in every Court and public office as they have by law and usage in the Courtsand public offices of the State or Territory from whence they are taken." State and Territorial Laws and Records Recognition Act \& I8 (I9OI-34), I Commonwealth Acts 957 (r935). See I Stat. 122 ( 1790 ), 28 U.S.C.A. 687 . 
cussion will show them to be, might be explained on purely sociological grounds. The root of America's problem lies, of course, in the fact that certain jurisdictions have made a business of migratory divorce.53 This policy has made all sister-state decrees suspect. But Nevada has never had an Australian counterpart. Perhaps the relatively small Australian population has rendered a divorce center impractical as a tourist business proposition. Perhaps the relative homogeneity of that population in matters of religion, culture, and occupation is manifested in remarkably similar laws on divorce.54 "Strict" law in one state has not made migration necessary or inviting. Lack of extremely "liberal" practice in another has left a domiciliary of a "strict" state with no place to go for more sympathetic law.

The constitutional differences must be discussed, interestingly enough, as the outgrowth of an Australian desire to avoid the development of a "Nevada" within the Commonwealth. The debates of the Australian Constitutional Convention reveal this comment: "If there is one blot which stands out more than another in the American Constitution it is that, by their Constitution, they are not able to deal with this [divorce] question in a uniform way; and we know that this has led to a condition of things socially of a most deplorable character. Persons who, according to the law of the state in which they reside, would have no chance of being divorced, may become domiciled in another state by living there a certain time and then, according to the laws of that state, may obtain divorce for reasons which, in their own state, would have been ludicrous as a ground of divorce."ss Thus urged, the Convention adopted provisions granting the federal parliament power to seize all legislative and judicial power in marriage and divorce and to provide uniform divorce law throughout the nation..$^{56}$ The Ameri-

53 'Before six o'clock this morning the county clerk's office began receiving divorce complaints for filing. At noon 17 o cases were on file and the total approached 300 before the office closed at night.... Two judges will start issuing decrees Monday in the uncontested cases brought today. The judges expect to grind them out at the rate of one every ten minutes and hope to clear up the grist of business by Wednesday." This, regarding Nevada's divorce business, appeared in the Philadelphia Record (May 3, r93I).

54 One notices an absence of mention of collusion as an element which might distinguish the statute law of a particular state from its practice. The absence of collusion might be explained by the presence of the Crown Proctor or Crown Solicitor who represent the interests of the state by investigating questionable divorce litigation. Amber v. Amber, (1937) S.A.S.R. 27; Stat. N.S.W. No. I4, § 30 (I899); Matrimonial Causes Act of 1875 (Qnsld.) \& 7 ; Matrimonial Causes Act 1929-36 (S.A.) Pt. IV, $\$ \$ 25,26$.

ss Australaian Federal 'Convention Debates I080 (I897); Quick and Garran, Annotated Constitution of the Australian Commonwealth 6ro (IgOr).

${ }^{56}$ Aust. Const. Act $\$ 51$ (xxii), $\$ 77$ (ii). "Reno has become possible in the United States of America because there was no general control of marriage and divorce legislation in that country. The framers of our Constitution no doubt had in mind the scandal that existed in America, where each state has its separate divorce laws, and where there was no possibility of federal control. ... If one Australian State did make conditions of divorce so attractive that people might be expected to flock to it to obtain divorces, this Parliament could effectively counteract such action. ..." r49 Commonwealth of Australia Parliamentary Debates 592, at $596(1935-36)$. 
can Constitution is unfortunately silent as to these matters and they remain the province of the state governments. 57

A discussion of the statutory differences demands a prefatory word explaining another distinction between the laws of the two countries. Under the "unitary domicile" principle of Australian law a wife could not obtain a domicile separate from that of her husband..$^{8}$ Thus when an Australian wife was deserted by a husband from another Commonwealth State, the courts of her own state were unable to grant her a divorce and the financial burden of following her husband often spelled an unseverable tie. To remove this hardship many Australian states had passed local statutes providing separate domicile for the deserted wife. 59 However, there was serious doubt whether divorces granted without conventional domicile could have extraterritorial effect, either among the Commonwealth States or outside the Commonwealth..$^{60}$ To remove the possibilities of uncertainty of status thus arising, the first permanent ${ }^{6 \mathrm{x}}$ federal statutes under the constitutional provisions above discussed were enacted. ${ }^{62}$ A nation-wide Australian domicile was created for the purposes, at least, of divorce jurisdiction. This federal jurisdiction was vested in the state courts. ${ }^{6} 3$ It might be invoked by any Australian domiciliary, whether husband or wife, who proved one year's residence in the forum state. ${ }^{64}$ The state domicile notion and the theory that a state should be allowed to control the marital contracts of its domiciliaries have not entirely lost their force, however. This is so since the law which the "resi-

37 U.S. Const. Amend. xo; McCarty v. Hollis, 120 F, 2d 540 (C.C.A. 1oth, I94x).

$s^{8}$ For criticism of unitary domicile: Lord Advocate v. Jaffey, (Ig2r) I A.C. I46; Salvesen v. Administrator of Austrian Property, (r927) A.C. 64r, 669-70. Contra: Barber v. Barber, 2 I How. (U.S.) 582 ( 1858 ).

59 New South Wales Matrimonial Causes Act of $1899 \S 16$; South Australian Matrimonial Causes Act of $I 929 \$ 43$; Victoria Marriage Act of 1928 \$ 75; Western Australia Supreme Court Act $\S 7$ I (I935); Tasmania Matrimonial Causes Act $\S 9$ (5) (I860), inserted by Matrimonial Causes Act $\$ 3$ (IgI9).

${ }^{60}$ Schache v. Schache, (I93I) S.R. (N.S.W.) 633,638; Domicile in Divorce, 2 Aust. L.J. I 83 (I928); An Australian Matrimonial Domicile, 9 Aust. L.J. 425 (I936); Chia v. Chia, (I92I) V.L.R. 566; I84 Commonwealth of Australia Parliamentary Debates $4350,4785,4833$ (1945); Isaacs, J., in Fremlin v. Fremlin, (I9I3) I6 C.L.R. 2I2, at 230: "Uncertainty in matrimonial relations is altogether to be deprecated and it is a scandal ... when a man and a woman are held to be man and wife in one country and strangers in another. . . . I would wish to draw the attention of the Commonwealth Parliament to the question."

6x Temporary Acts were passed during both World Wars in order to enable Australian wives to obtain divorces from their British and American husbands without the necessity of following the servicemen to their foreign domiciles. Matrimonial Causes (Expeditionary Forces) Act (IgIg); I7 Commonwealth Acts 66 (I920); Matrimonial Causes Act (Cth., I945); I84 Commonwealth of Australia Parliamentary Debates 4350, 4785, 4833 (I945); Black v. Black, (I946) Q.W.M. 50.

62 Matrimonial Causes Act (Cth., I945), commented on, McWilliam, The Matrimonial Causes Act, ig Aust. L.J. 330 (I946).

${ }^{63}$ Aust. Const. Act $\$ 77$ (iii).

64 Matrimonial Causes Act $\S$ ro (Cth., I945); Caldwell v, Caldwell, (I946) S.A.S.R. I85; Stevens v. Stevens, (r946) V.L.R. 283. 
dence" court must apply is that of the state of domicile. ${ }^{65}$ Certainty of effect is breathed into the decree of the "residence" court by a provision that any divorce granted under the Act is to be "of the same force and effect as if that judgment" had been given by the court of domicile. ${ }^{66}$

The advantages of the legislation are clearly seen. It reconciles what early portions of this note referred to as the competing notions of "states' rights" and the drive for certainty. It leaves to the states a type of "local option"in deciding how marriages are to be dissolved. Federal power is present but unexercised. At the same time a divorce decree enjoys a high degree of validity when brought into the courts of another state. Paraphrased in American terms, it would be possible for a Nevada court to give a New Yorker temporarily present in $\mathrm{Ne}$ vada a decree entitled to "full faith and credit" anywhere in the United States providing that it applied the New York substantive divorce law.

The objection to American adoption of such an act lies, of course, in the fact that a Nevada court might be disposed to find a fictitious Nevada domicile in order to give the petitioner relief under Nevada's more liberal practice. But it must not be forgotten that a constitutional amendment giving the federal government ultimate powers to exclude state variance in marriage and divorce law would be a necessary precursor of American adoption of the Act. Under such an amendment Nevada and other states like her would have "everything to lose and nothing to gain" by continued migratory divorce practice. If Nevada voluntarily gave up her migratory divorce business she would retain the right to stipulate divorce policy for her own domiciliaries. If Nevada persisted in fictitious findings of domicile for the benefit of her tourist trade, the Congress would deprive her of the business as well as rights over her own citizens by passing a federal substantive divorce law.

The difficulties of constitutional amendment in the United States would be the greatest obstacle to successful adoption of the Australian program. Almost perennial attempts have been made to secure an amendment relating to divorce and thus far they have failed.$^{67}$ At one pole these attempts are met by opinions from strong anti-divorce regions whose constituents found their beliefs on religious faith. At the other stands the Nevada business man, for whom the liberal divorce law and practice of that State are matters of competition for the tourist trade. It might seem that legislators who truly reflected the desires of either polar group could not conscientiously support a constitutional change which

\footnotetext{
65 Matrimonial Causes Act $\S$ II (Cth., I945). "Practice and procedure" is to be that of the forum court, not the court of domicile. The form of a decree nisi and the period to elapse between the decree nisi and the decree absolute is a matter of "practice and procedure" under the Act. White v. White, (I947) V.L.R. 434; Tullett v. Tullett, (I947) Q.W.N. 55. Contra: Green v. Green, (I947) Q.W.N. 16.

${ }_{65}$ Matrimonial Causes Act \& $\mathrm{I}_{3}$ (Cth., $\mathrm{x}_{945}$ ).

${ }_{67}$ Justice Frankfurter states that, beginning in $\mathrm{r} 88_{4}$, almost seventy constitutional amendments concerning marriage and divorce law have been proposed. Sherrer v. Sherrer, 334 U.S. $343,3^{64}$ n. I3 (1948).
} 
would compromise either strictness or liberality for a federal middle ground. And yet, apart from churches and business men and other peculiarly interested groups, one must believe that a substantial majority of Americans could reach a high degree of unanimity concerning divorce. For example, the prevalence of collusive divorce in the strict jurisdictions argues that state legislators are out of step with the demand for liberalization of divorce law.$^{68} \mathrm{It}$ is true, also, that old historical reasons for variance, such as the frontier's shortage of women and the conservatism of rural areas are disappearing. Modern communication and transportation are substantially intermingling the populations of the various states and should in time create an attitude toward divorce even more homogeneous than that which prevails at present among the general population.

In discussing the distinctions between American and Australian case law in this field, it might seem unjustifiable to dwell on a decision of an isolated state court which is so contrary to accepted principles that it cannot yet be said to indicate a representative trend. But the Victorian Court's decision in Harris v. Harri $^{69}$ is interesting in that it reveals Australian judicial nonchalance at the exact point which is crucial to the American problem. In that case a petitioner for divorce revealed to the court that his first wife had obtained a previous divorce in New South Wales. However, no evidence was presented that the petitioner had ever lost his Victorian domicile and had become a domiciliary of New South Wales, a prerequisite to the acquisition of jurisdiction by the New South Wales court under Australian unitary domicile principles..$^{\circ}$ If jurisdiction was lacking, the prior decree was not entitled to extraterritorial effect. Such a result would follow from both the common law and the American interpretations of full faith and credit clauses. The petitioner's first marriage subsisted. There was no second marriage capable of dissolution by the Victorian Court. Yet, after a careful review of the American decisions, Justice Fullager decided that the statutory "full faith" provisions, ${ }^{72}$ if not the constitutional clause," altered the common law and commanded him to recognize the validity of the New South Wales decree even though given without jurisdiction.

The American bar will wonder how Justice Fullager might have reached such

68 c $[F]$ ree consent divorce exists in the United States as a fact. Not as a divorce-mill phenomenon alone. But as a standard practice of divorce, to the tune of 100,000 cases annually or more, throughout the country." Llewellyn, Behind the Law of Divorce, 33 Col. L. Rev. 249, 285 (1933).

${ }^{69}$ (I947) V.L.R. 44, noted in 2 Int. L.Q. 2I (I948); 2I Aust. L.J. 358 (I947); Morison, Extra-territorial Enforcement of Judgments Within the Commonwealth of Australia, $2 I$ Aust. L.J. 298 (I947). Perry v. Perry, (I947) V.L.R. 470 (semble).

$7^{\circ}$ The New South Wales Matrimonial Causes Act of $1899 \S \mathrm{r}$, provided for separate domicile of deserted wives. However, the petitioner's former wife brought the New South Wales action on grounds of adultery under $\S$ I 5 of that act which required the petitioner's domicile within the state at the relevant time.

${ }^{7 x}$ State and Territorial Laws and Records Recognition Act $\S 18$ (xgox-34); I Commonwealth Acts 957 ( 1935 ).

${ }^{72}$ Aust. Const. Act $\$$ II8. 
a conclusion. His opinion reveals that he was apprised of the American difficulty. Three reasons have already been suggested. ${ }^{73} \mathrm{~A}$ fourth explanation appears in the differences between Australian and American case-law interpretation of the "full faith" clauses. D'Arcy v. Ketchum"4 and Thompson v. Whitman ${ }^{75}$ did not have Australian counterparts. From what can be determined at so great a distance from Australia, Australian courts had not expressly said, as did the American courts in the cases referred to above, that the "full faith" clauses did not apply to recitals of jurisdictional facts contained in foreign state decrees. It seems that the notion of collateral attack on grounds of want of jurisdiction was simply accepted by Australian lawyers and that they had previously paid little attention to the mandates of the clauses which, by their terms are certainly suffciently broad to deny such attack. ${ }^{76}$ In Australian divorce cases reference to "full faith" is to be found only once prior to the Harris decision. In Jones v. Jones77 a dissenting opinion expressed belief that the clauses demanded recognition of an ex parte decree when valid in the state where rendered. This apparent vacuum of decision made it easier for Justice Fullager to exercise discretion in the matter.

Although it seems safe to assume that the Harris case will affect only the recognition of divorce decrees and will not intrude upon such fact situations as that presented in the American case of Thompson $v$. Whitman, ${ }^{78}$ it is interesting to note that the decision importantly affects the working of the Act discussed above. Its scope is sufficiently wide to forestall collateral attack on a sisterstate's finding of the required one year's residence as well as an attack on the finding of domicile for the purposes of determining the applicable law.

But perhaps the outstanding feature of the decision for purposes of comparison is its easy recognition of a rule which dissolves entirely the "uncertainty" aspects of the American dilemma. It demonstrates in a very real way that the notion of "states' rights" which in America competes with the desire to eliminate "uncertainty," is of relatively minor importance in Australian judicial thought on this subject. Once again the absence of an Australian "Reno," the lack of variation in divorce policy among the Commonwealth states and the constitu-

73 I) Absence of variance in social policy concerning divorce among Australian States. 2) Absence of the problem which would have been presented by an Australian "Reno" and an underground railroad of migratory divorce. 3) Probability that Australia would never be confronted with the "Reno Problem" since the Commonwealth Parliament had ultimate power. These were suggested by Justice Fullager's opinion. Harris v. Harris, (I947) V.L.R. 44,58 .

74 II HOW. (U.S.) I65 (I850).

75 I 8 Wall. (U.S.) 457 ( 1873 ).

${ }^{76}$ Perhaps one reason for this lack of attention is the statutory method of sister state judgment execution in Australia. Service and Execution of Process Act (IgOI-34). Under a similar statutory method attack was surely allowed prior to the Constitution and its full faith and credit clause. Donald v. Donald, (I899) 9 Q.L.J. 21 r. After it, attack was allowed without reference to the clauses. Kane v. Kane, (r939) Q.W.N. $5^{8 .}$

77 (I928) 40 C.L.R. 3I5, aff'd (I928) V.L.R. 24.

${ }^{8} \mathrm{I} 8$ Wall (U.S.) 457 ( 1873 ). 
tional power of the federal Parliament to act in the field are thrown into sharp contrast with what Australians must deem the unfortunate situation in the United States.

\section{GUILT BY ASSOCIATION-THREE WORDS IN SEARCH OF A MEANING}

\section{I}

In those days they shall say no more. The fathers have eaten a sour grape and the children's teeth are set on edge. But every man shall die for his own iniquity; every man that eateth the sour grape, his teeth shall be set on edge. ${ }^{x}$

The Nuremberg trials, the President's Loyalty Order, and the recent efforts to obtain convictions of Communist Party leaders have evoked criticism by lawyers and laymen alike. The brunt of these attacks has been directed at the techniques employed to establish the criminal responsibility of persons affiliated with associations and groups whose activities have been felt to endanger national security. Writers criticizing these efforts have employed a phrase which has recently become an important addition to the popular vocabulary - guilt by association. ${ }^{2}$ The emotional responses evoked by the phrase arise not alone from the highly charged character of the words themselves but also from the fact that they are used to describe highly controversial proceedings. While the term is employed in an increasing variety of situations, few have devoted any serious effort to assign it any clear meaning.

That guilt by association is a concept repugnant to Anglo-American notions of justice is explicable to some extent from the tacit assumption that "it is of the very essence of our deep rooted notions of criminal liability that guilt be personal and individual."'3 The doctrine of personal guilt has no clear historic origin, and unlike other major assumptions of the common law, it has been the subject of little or no inquiry. While British and American experience has displayed some consciousness of class and family discrimination, the absence of any rigid caste structure has permitted the development of a legal system which tends to evaluate rewards and punishments in terms of individual achievement

I Jeremiah 3r: 29-30.

2 For judicial references to guilt by association see Justice Murphy, concurring in Bridges v. Wixon, 326 U.S. I35, I63 (1945); Dunne v. United States, I38 F. 2d I37, I43 (C.C.A. 8th, I943), cert. den. 320 U.S. 790 (r943). For discussions of the doctrine of guilt by association as it relates to special problems see Chafee, Free Speech in the United States 470-84 (I94I); Emerson, Loyalty Among Government Employees, 58 Yale L.J. I, 9I-94 (r948); O'Brian, Loyalty Tests and Guilt by Association, 6r Harv. I. Rev. 592 (I948); Gellhorn, Report on a Report of the House Committee on Un-American Activities, 60 Harv. I. Rev. II93, I217-24 (I947); Constitutionality of the Taft-Hartley Non-Communist Affidavit Provision, $48 \mathrm{Col}$. L. Rev. 253, 26I-63 (I948); Wechsler, The Issues of The Nuremberg Trial, 62 Pol. Sci. Q. II, 2I23 (I947); Guilt By Association, University of Chicago Round Table No. 573 (Mar. I3, I949).

3 Sayre, Criminal Responsibility for Acts of Another, 43 Harv. L. Rev. 659, 7I7 (I930); see Knauer v. United States, 328 U.S. 654, 669 (I946); Kotteakos v. United States, 328 U.S. 750, $77^{2}$ (I946); Schneiderman v. United States, 320 U.S. II8, I36 (I943). 